\title{
Phytomass and Specific Diversity of Macrophyte Vegetation in the Middle Reach of the Yenisei River
}

Tatiana A. Zotina* Institute of Biophysics $S B$ RAS, 50/50, Akademgorodok, Krasnoyarsk, 660036, Russia

Received 03.08.2013, received in revised form 17.06.2013, accepted 15.01.2014

Phytomass and specific diversity of macrophytes of the Yenisei River on the stretch from Krasnoyarsk to the mouth of the Angara River were estimated. The investigation showed that littoral macrophyte vegetation clearly differs in specific composition and biomass in the deep water $(H>0,8 \mathrm{~m})$ and shallow water $(H<0,7 \mathrm{~m})$ zones. Potamogeton lucens principally dominates in deep-water communities; several dominating species are noticed in the shallow-water zone (P.perfoliatus, P.pectinatus, Elodea canadensis and some other species). The average biomass of deep-water macrophytes on the stretch of the river (431 $101 \mathrm{~g} / \mathrm{m}^{2}$ D.W., $\left.n=15, S D\right)$ was 2.5 times higher $(p<0,01)$ than the biomass of shallowwater vegetation $\left(172 \pm 81 \mathrm{~g} / \mathrm{m}^{2}, n=15\right)$. Phytomass loss observed in the two dominating species of pondweed, P. lucens and P.perfoliatus, during the season of vegetation was $3.1 \pm 3.4 \%(n=17)$ and $11.6 \pm 7.8 \%$ (n=37), respectively. Biomass production of P.lucens ranged from 240 to $630 \mathrm{~g} / \mathrm{m}^{2}$, biomass production of P.perfoliatus was $360 \mathrm{~g} / \mathrm{m}^{2}$. The estimated Shannon-Margalef index (based on dry biomass) revealed higher specific diversity of the shallow-water macrophyte vegetation as compared to the deep-water one on the majority of sampling sites, but the mean values did not differ statistically $(0,90 \pm 0,78$ u 0,53 $\pm 0,55, n=15)$. The biomass and diversity of macrophytes of the Yenisei River did not change considerably at different distances away from the sources of technogenic pollution of the river.

Keywords: biodiversity, biomass, loss of biomass, Shannon-Margalef index, submersed macrophytes, Yenisei River.

(C) Siberian Federal University. All rights reserved

* Corresponding author E-mail address: t_zotina@ibp.ru 


\title{
Фитомасса и видовое разнообразие макрофитной растительности \\ в среднем течении р. Енисей
}

\author{
T.А. Зотина \\ Институт биофизики СО РАН \\ Россия, 660036, Красноярск, Академгородок, 50/50
}

Оченена фитомасса и видовое разнообразие макрофитов $p$. Енисей на участке от 2. Красноярска до устья р. Ангары. Исследование показало, что прибрежная макрофитная растительность четко разделяется по видовому составу и биомассе на глубоководную $(H>0,8$ м) и мелководную $(H<0,7$ м). В глубоководных сообществах доминирует, в основном, рдест блестящий, в мелководных отмечено доминирование нескольких видов макрофитов (рдеста стеблеобъемлющего, рдеста гребенчатого, элодеи канадской и др. ). Усредненная биомасса глубоководной растительности на всем участке $\left(431 \pm 101\right.$ г сух. массы/ $/ \mathrm{M}^{2}, n=15$, станд. отклон.) в 2,5 раза $(p<0,01)$ превышает биомассу мелководной $\left(172 \pm 81\right.$ г/ $\left.\mathrm{m}^{2}, n=15\right)$. Потери фитомассы (опад) двух доминирующих видов рдестов Potamogeton lucens и P. perfoliatus

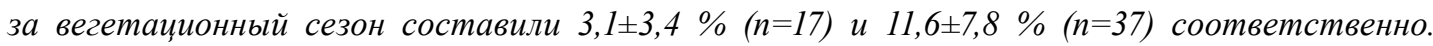

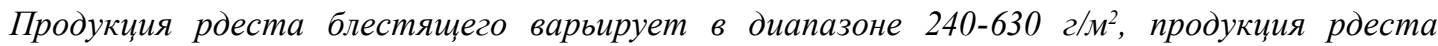
стеблеобъемлющего составила 360 г/. ${ }^{2}$. Оченка по индексу Шеннона-Маргалефа (на основе сухой фитомассы) показала более высокое видовое разнообразие мелководной макрофитной растительности, по сравнению с глубоководной на большинстве участков отбора проб, но

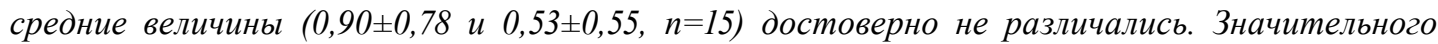
изменения биомассы и видового разнообразия макрофитов р. Енисей на разном удалении от источников антропогенного загрязнения не выявлено.

Ключевые слова: биомасса, индекс Шеннона-Маргалефа, опад, погруженные макрофиты, видовое разнообразие, река Енисей.

Погруженные макрофиты являются ната (ГХК) госкорпорации «Росатом», расповажным средообразующим компонентом ложенного в г. Железногорске, используются пресноводных экосистем. Они выполняют продукционную функцию и участвуют в самоочищении водоема, накапливая ксенобиотики в своей биомассе, и поэтому широко используются как индикаторы антропогенного загрязнения (Куриленко, Осмоловская, 2007; Fabris et al., 2009; Ceschin et al., 2010). Макрофиты р. Енисей, произрастающие в зоне влияния промышленно-коммунального комплекса г. Красноярска и Горно-химического комбидля биомониторинга техногенного загрязнения и экотоксикологических исследований реки (Болсуновский и др., 2007; Анищенко и др., 2010; Кропачева и др., 2011; Зотина и др., 2013). Погруженные макрофиты составляют основу водной растительности среднего участка р. Енисей, от плотины Красноярской ГЭС до устья р. Ангары (Zotina, 2008).

Цель данной работы - оценить современное состояние макрофитов (биомассу и 
видовое разнообразие) на среднем участке p. Енисей. Растительность водотоков Сибири изучена в меньшей степени (Токарь, 2005; Киприянова, 2009, 2013; Евженко, 2010; Chepinoga et al., 2011), чем в европейской части России (Бобров, 1999; Папченков, 2003а; Бобров, Чемерис, 2005, 2011; Шарапов и др., 2013). К тому же большинство современных работ посвящено исследованию растительного покрова малых рек. Наша работа частично заполнит недостаток информации по состоянию растительности крупной сибирской реки.

\section{Материалы и методы}

Река Енисей - одна из крупнейших рек Российской Федерации, ее протяженность от места слияния Малого Енисея и Большого Енисея составляет 3385 км. Протяженность среднего участка реки от Красноярской ГЭС до устья р. Ангары - 364 км. Наиболее крупные притоки на этом участке - p. Мана (26 км) и р. Кан (106 км). Скорость течения на плесовых участках составляет 4-5 км/ч, на перекатах возрастает до 10 км/ч, на порогах - до 16-18 км/ч. При высоких уровнях воды скорость течения на плесовых участках увеличивается. Уровенный режим всецело зависит от ресурсов Красноярского водохранилища и режима работы ГЭС. Климат в средней части p. Енисей резко континентальный, среднегодовая температура воздуха положительная. Переход среднесуточной температуры воздуха через $0{ }^{\circ} \mathrm{C}$ случается в конце второй декады апреля. В июле, самом теплом месяце, средняя температура воздуха достигает $20{ }^{\circ} \mathrm{C}$. В первой декаде сентября средние температуры переходят через $10{ }^{\circ} \mathrm{C}$ в сторону понижения. Переход температуры через ноль в сторону отрицательных температур наблюдается во второй декаде октября. Зимний период начинается в конце октября - первых числах ноября и продолжается 5-5,5 месяца. Сред- няя температура зимнего периода составляет минус $17,7^{\circ} \mathrm{C}$. Более подробные гидрографические сведения приведены в лоции р. Енисей (Карта реки..., 2008). По данным 19721974 гг. (Дрюккер, Петрова, 1988) и 1984-1987 (Приймаченко и др., 1993), температура воды в поверхностном слое Енисея на участке от плотины Красноярской ГЭС до устья Ангары достигает максимальных значений в июлеавгусте и не превышает $18{ }^{\circ} \mathrm{C}$. В июле-августе 1984-1987 гг. средняя величина температуры в поверхностном слое воды реки колебалась в диапазоне 7,6-12,0 ${ }^{\circ} \mathrm{C}$.

Погруженные макрофиты собирали в 2003-2012 гг. на среднем участке Енисея, от пос. Удачный (около 14 км вверх по течению от речного вокзала г. Красноярска со стороны левого берега) до пос. Стрелка (325 км от Красноярска, выше устья Ангары) со стороны правого берега (рис. 1). Все станции отбора, за исключением станции вблизи пос. Удачный, находились вблизи правого берега р. Енисей. Координаты и краткая характеристика мест отбора проб представлены в табл. 1. Площадки для описания растительности выбирали с учетом рекомендаций (Бобров, Чемерис, 2003). Отбор проб (укосы) фитомассы проводили в период с 3-й декады августа по 3-ю декаду сентября с помощью рамки площадью $0,5 \mathrm{~m}^{2} \mathrm{c}$ учетом рекомендаций (Абакумов, 1983). Пробы отбирали в глубоководной (глубина 0,8 м и более) и в мелководной (глубина до 0,7 м) зонах рипали по 3-7 повторностей (рамок) в каждой. В монодоминантных сообществах обычно отбирали меньшее число повторностей, чем в полидоминантных. За весь период исследования было сделано 165 укосов. Для сравнения биомассы и видового разнообразия сообщества макрофитов глубоководной и мелководной зон были использованы только данные укосов, сделанных в сообществах, занимавших наибольшую площадь проектив- 


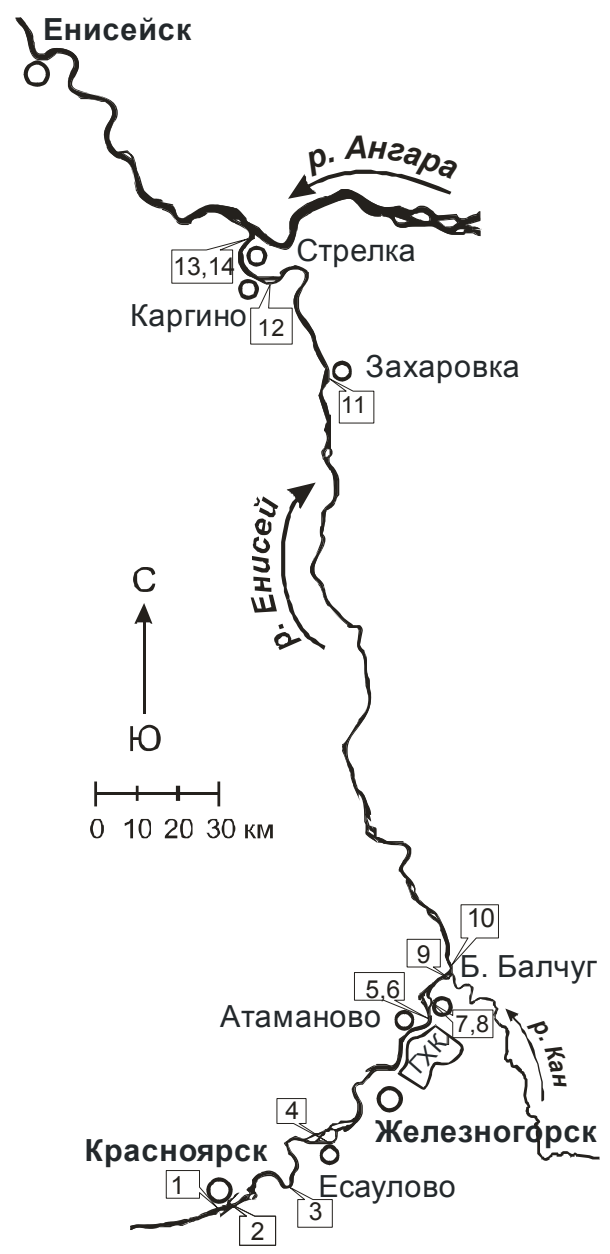

Рис. 1. Карта-схема среднего участка р. Енисей. Номерами отмечены станции отбора проб макрофитов

ного покрытия на исследуемых участках (56 и 53 укоса для глубоководной и мелководной зоны соответственно).

Фитомассу отбирали с борта лодки или с берега, в зависимости от глубины воды и толщины слоя донных отложений, руками и при помощи специально модифицированных для этой цели садовых грабель с более частыми и длинными зубцами. Собранную фитомассу промывали в проточной воде, упаковывали в полиэтиленовые мешки и привозили в лабораторию, где растения сортировали по видам, удаляли корни и сушили сначала на воздухе, а затем в сушильном шкафу при $80{ }^{\circ} \mathrm{C}$ до постоянной массы. Достоверность различия средних значений биомассы глубоководной и мелководной зон оценивали с помощью двухвыборочного t-теста, на графиках в качестве ошибок приведены стандартные отклонения среднего.

Видовое разнообразие макрофитов $(\mathrm{H})$ оценивали по индексу Шеннона-Маргалефа (Мордухай-Болтовской, 1975; Алимов и др., 1979) на основе средних величин сухой фитомассы по формуле

$$
\mathrm{H}=-\Sigma\left[\left(\mathrm{b}_{\mathrm{i}} / \mathrm{B}\right) \cdot \log _{2}\left(\mathrm{~b}_{\mathrm{i}} / \mathrm{B}\right)\right]
$$

где $\mathrm{b}_{\mathrm{i}}$ - биомасса вида, В - суммарная биомасса растений. Индекс рассчитывали для 
Таблица 1. Описание мест отбора растений

\begin{tabular}{|c|c|c|c|}
\hline $\begin{array}{c}\text { Номер } \\
\text { станции }\end{array}$ & Координаты & $\begin{array}{c}\text { Расстояние от г. Красноярска } \\
\text { по судоходной карте } \\
\text { [Карта реки..., 2008], км }\end{array}$ & $\begin{array}{c}\text { Место отбора, } \\
\text { ближайший населенный пункт }\end{array}$ \\
\hline 1 & $\begin{array}{l}55^{\circ} 58^{\prime} \text { с.ш. } \\
92^{\circ} 39^{\prime} \text { в.д. }\end{array}$ & -14 & $\begin{array}{l}\text { Со стороны левого берега р. Енисей, пос. } \\
\text { Удачный }\end{array}$ \\
\hline 2 & $\begin{array}{l}55^{\circ} 59^{\prime} \text { с.ш. } \\
92^{\circ} 53^{\prime} \text { в.д. }\end{array}$ & -1 & $\begin{array}{l}\text { Со стороны правого берега о-ва Отдыха, } \\
\text { на территории г. Красноярска }\end{array}$ \\
\hline 3 & $\begin{array}{l}\text { 560'ㅅ․․ } \\
93^{\circ} 09^{\prime} \text { в.д. }\end{array}$ & 26 & $\begin{array}{l}\text { Со стороны правого берега коренного } \\
\text { русла р. Енисей, пос.Березовка }\end{array}$ \\
\hline 4 & $\begin{array}{l}56^{\circ} 08^{\prime} \text { с.ш. } \\
93^{\circ} 16^{\prime} \text { в.д. }\end{array}$ & 44 & $\begin{array}{l}\text { Правый берег р. Енисей, выше о-ва } \\
\text { Есаульского, с. Есаулово }\end{array}$ \\
\hline 5 & $\begin{array}{l}56^{\circ} 23^{\prime} \text { с с.ш. } \\
93^{\circ} 39^{\prime} \text { в.д. }\end{array}$ & 85 & $\begin{array}{l}\text { Вдоль правого берега косы Атамановской, } \\
\text { с. Атаманово }\end{array}$ \\
\hline 6 & $\begin{array}{l}56^{\circ} 23^{\prime} \text { с с.ш. } \\
93^{\circ} 37^{\prime} \text { в.д. }\end{array}$ & 87 & $\begin{array}{l}\text { Вдоль правого берега о-ва Атамановского, } \\
\text { с. Атаманово }\end{array}$ \\
\hline 7 & $\begin{array}{l}56^{\circ} 25^{\prime} \text { с.ш. } \\
93^{\circ} 41^{\prime} \text { в.д. }\end{array}$ & 92 & $\begin{array}{l}\text { Со стороны правого берега вблизи устья } \\
\text { р. Большая Тель, с. Б. Балчуг }\end{array}$ \\
\hline 8 & $\begin{array}{l}56^{\circ} 27^{\prime} \text { ' с.ш. } \\
93^{\circ} 41^{\prime} \text { в.д. }\end{array}$ & 96 & Протока о-ва Березового, с. Б. Балчуг \\
\hline 9 & $\begin{array}{l}56^{\circ} 30^{\prime} \text { с с.ш. } \\
93^{\circ} 46^{\prime} \text { в.д. }\end{array}$ & 105 & Протока о-ва Тарыгин, с. Усть-Кан \\
\hline 10 & $\begin{array}{l}56^{\circ} 32^{\prime} \text { ' с.ш. } \\
93^{\circ} 47^{\prime} \text { в.д. }\end{array}$ & 108 & $\begin{array}{l}\text { Со стороны правого берега ниже устья } \\
\text { р. Кан, с. Усть-Кан }\end{array}$ \\
\hline 11 & $\begin{array}{l}57^{\circ} 47^{\prime} \text { с.ш.ш. } \\
93^{\circ} 17^{\prime} \text { 'в.д. }\end{array}$ & 272 & Протока о-ва Журавлев, с. Захаровка \\
\hline 12 & $\begin{array}{l}58^{\circ} 01^{\prime} \text { с с.ш. } \\
92^{\circ} 57^{\prime} \text { в.д. }\end{array}$ & 317 & $\begin{array}{l}\text { Протока о-ва Большой Каргинский, с. } \\
\text { Новокаргино }\end{array}$ \\
\hline 13 & $\begin{array}{l}58^{\circ} 04^{\prime} \text { с с.ш. } \\
92^{\circ} 59^{\prime} \text { в.д. }\end{array}$ & 324 & $\begin{array}{l}\text { Со стороны левого берега о-ва Лопатин и в } \\
\text { протоке, пос. Стрелка }\end{array}$ \\
\hline 14 & $\begin{array}{l}58^{\circ} 05^{\prime} \text { с.ш. } \\
92^{\circ} 59^{\prime} \text { в.д. }\end{array}$ & 325 & $\begin{array}{l}\text { Со стороны правого берега и в ухвостье } \\
\text { о-ва Черемухового, пос. Стрелка }\end{array}$ \\
\hline
\end{tabular}

сообщества макрофитов, занимающего наибольшую площадь проективного покрытия.

Потери биомассы за период вегетации (опад) оценивали однократно в сентябре 2008 г. для двух массовых видов рдеста Potamogeton lucens и $P$. perfoliatus, отобранных вблизи с. Атаманово и пос. Стрелка соответственно. Длина растений от верхушки до корня составляла 1,4-2,5 и 0,8-1,3 м соответственно. Всего для оценки опада было использовано 17 растений рдеста блестящего и 37 - рдеста стеблеобъемлющего. У надземной части растений определяли число утраченных листьев. Оставшиеся листья отделяли от стеблей, сушили и взвешивали. Массу утраченных листьев приравнивали к средней массе близких по размеру листьев и рассчитывали потерю фитомассы в \%. Результаты приведены в виде средних величин со стандартным отклонением.

Виды макрофитов идентифицировали в основном с помощью определителей (Красноборов и др., 2000; Губанов и др., 2002). Номенклатура таксонов сосудистых растений дана по С.К. Черепанову (1995).

\section{Результаты и обсуждение}

На исследованных участках Среднего Енисея (рис. 1) нами были встречены погру- 
Таблица 2. Перечень видов макрофитов, встреченных на участках отбора проб

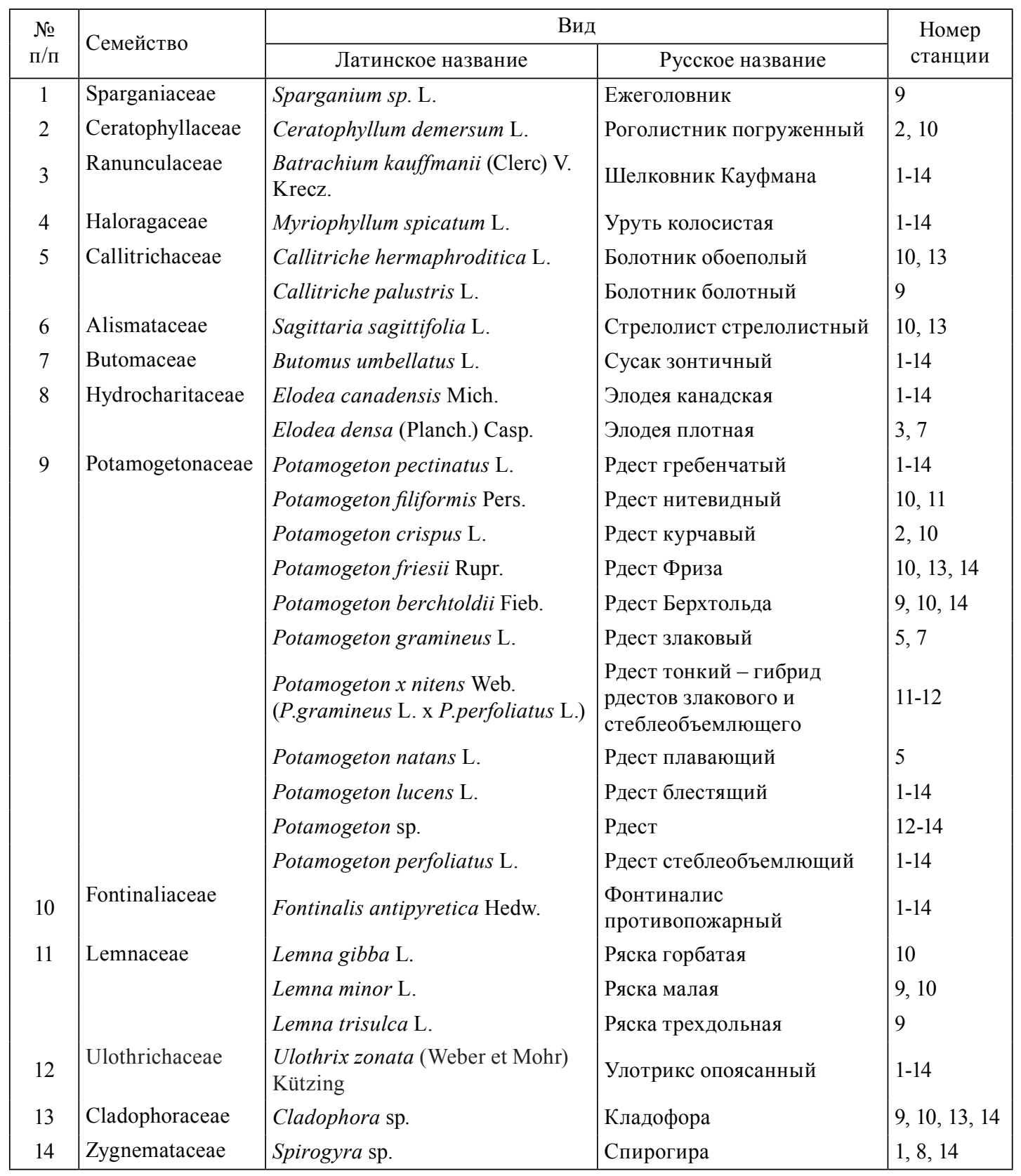

женные макрофиты, относящиеся к 14 семействам (табл. 2). Наиболее разнообразно в видовом отношении были представлены рдесты. По сравнению с предыдущими исследованиями (Zotina, 2008) перечень встреченных нами макрофитов пополнился одним видом ежеголовника (Sparganium sp.), одним видом болотника (Callitriche palustris), одним видом элодеи (Elodea densa), двумя видами рдеста (Potamogeton crispus и P. bercholdii), тремя видами ряски (Lemna gibba, L. minor, L. trisulca), a также нитчатыми зелеными водорослями Ulothrix zonata, Cladophora sp. и Spirogyra sp. (последние встречались нам и ранее, но в спи- 
сок не включались). Ранее из макроскопических зеленых водорослей для Енисея упоминался Hydrodiction (Приймаченко и др., 1993). Вышеперечисленные виды сосудистых растений массовых зарослей в Енисее не образуют. Элодея плотная встречалась в 2011-2012 гг. в двух точках на удалении 23 и 93 км от Красноярска (Зотина, 2013). Рдест курчавый встретился нам в виде единичных растений в черте Красноярска (станция 2, табл. 1) и ниже устья p. Кан (станция 10). Рдест Берхтольда наблюдался в протоке о. Тарыгин (станция 9), ниже устья р. Кан (станция 10) и вблизи пос. Стрелка (станции 13 и 14). P. crispus и P. berchtoldii отмечались также в низовье Енисея (Щербина, 2009). Ежеголовник встретился нам в августе 2012 г. в виде небольшой куртины в заводи со стороны правого берега о. Тарыгин (станция 9), выше устья р. Кан, хотя ранее представители этого рода упоминались как массовые на данном участке Енисея (Приймаченко и др., 1993).

Заросли погруженных макрофитов были сосредоточены в основном вблизи островов, в протоках, а также в заводях и вдоль берегов коренного русла Енисея. Встречались как группировки (куртины фонтиналиса, элодеи канадской, шелковника Кауфмана и др. ), так и сплошные одно- или двухъярусные заросли погруженных макрофитов, нижний ярус наиболее часто образовывали элодея канадская и болотник обоеполый, а верхний - уруть колосистая, рдест стеблеобъемлющий и рдест блестящий.

Прибрежная макрофитная растительность четко разделялась по видовому составу на мелководную и глубоководную. Условно границу можно провести по глубине около одного метра при нормальном уровне воды. В глубоководной зоне преобладали монодоминантные сообщества макрофитов с проективным покрытием доминанта около 90-
$100 \%$. Основу глубоководной макрофитной растительности на проточных участках, в том числе граничащих с основным руслом реки, составлял рдест блестящий на большинстве участков отбора. В протоках со слабым течением и в заводях наиболее часто доминировал рдест стеблеобъемлющий. Элодея канадская массово развивается на участках с замедленным течением глубиной до двух метров. В прибрежной полосе на глубине менее одного метра на ряде участков массово развивается рдест тонкий, рдест гребенчатый и другие виды рдестов, упомянутые в списке (табл. 2). В мелководной зоне наибольшую площадь проективного покрытия на исследованных нами участках занимали полидоминантные сообщества макрофитов, а также монодоминантные сообщества рдеста стеблеобъемлющего, рдеста гребенчатого, элодеи канадской и др.

Исходя из вышеупомянутых различий прибрежной макрофитной растительности глубоководной и мелководной зон рипали Енисея, были рассчитаны коэффициенты видового разнообразия для этих двух зон (рис. 2a, б). Величины индекса ШеннонаМаргалефа для макрофитных сообществ мелководной зоны изменялись в диапазоне от 0,01 до 2,3 бит, составляя на всем исследованном участке реки в среднем $(0,90 \pm 0,78)$ бит $(\mathrm{n}=15)$. Индекс видового разнообразия глубоководной макрофитной растительности изменялся от 0,00 до 1,94 , составляя в среднем $(0,53 \pm 0,55)$ бит $(\mathrm{n}=15)$. На ряде исследованных участков разнообразие макрофитов в мелководной зоне выше, чем в глубоководной, однако средние величины индексов достоверно не различаются $(\mathrm{p}<0,05)$. В некоторых протоках, например Балчуговской (94 км от Красноярска), разнообразие макрофитов на глубине довольно высокое (рис. 2a). 

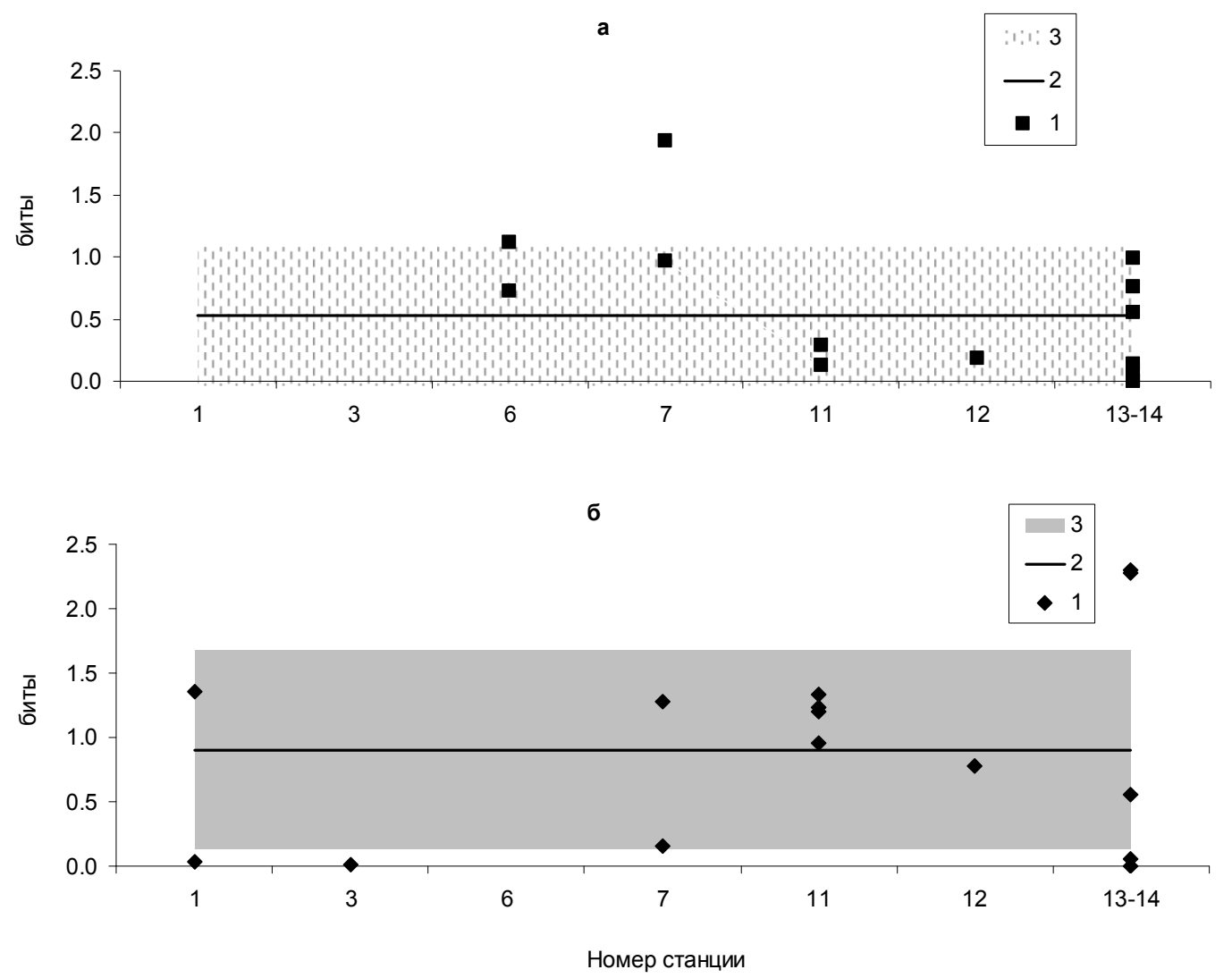

Рис. 2. Видовое разнообразие макрофитных сообществ глубоководной (a, H $>0,8$ м) и мелководной $($ б, Н $<0,7$ м) зон рипали р. Енисей на разном удалении от г. Красноярска: 1 - значения индекса ШеннонаМаргалефа (биты); 2 - среднее значение индекса на всем участке для глубоководной и мелководной зон рипали; 3 - стандартное отклонение среднего. Расположение станций относительно г. Красноярска по течению р. Енисей: № 1 - 14 км выше Красноярска по течению реки; остальные станции расположены ниже Красноярска: № 3 - 26 км, № 6 - 87 км, № 7 - 92 км, № 11 - 272 км, № 13-14 - 324-235 км

Биомасса глубоководной макрофитной растительности в сообществах, занимавших наибольшую площадь проективного покрытия на исследованных участках, составляла от

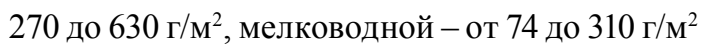
(рис. 3). Значительного изменения фитомассы на квадратном метре растительного покрова по мере удаления от Красноярска не наблюдалось, что позволяет усреднить данные. В результате средняя величина биомассы глубоководной растительности составила $(431 \pm 101)$ г/ $\mathrm{M}^{2}(\mathrm{n}=15)$ (рис. 3). На большинстве участков в глубоководной зоне доминировал рдест блестящий на уровне 53-100 \%. Биомасса рдеста блестящего в монодоминантных сообществах этого вида варьировала от 240 до 630 г/ $\mathrm{m}^{2}$, составляя в среднем $391 \pm 109$ г/M² $(\mathrm{n}=12)$. На трех участках отбора доминировали другие виды. Так, вблизи пос. Стрелка (станция 14) в глубоководной зоне доминировал рдест стеблеобъемлющий на уровне $100 \%$, в 2008 г. его биомасса равнялась $(325 \pm 69) \Gamma / \mathrm{M}^{2}(\mathrm{n}=3)$; на станции 8 вблизи с. Б. Балчуг в 2007 г. доминировала элодея на уровне 72 \% от общей биомассы, которая составила $(567 \pm 165)$ г $/ \mathrm{M}^{2}(\mathrm{n}=6)$. Вблизи пос. Стрелка отмечены участки, занятые монодоминантным сообществом рдеста гребенчатого, вклад которого в общую био- 


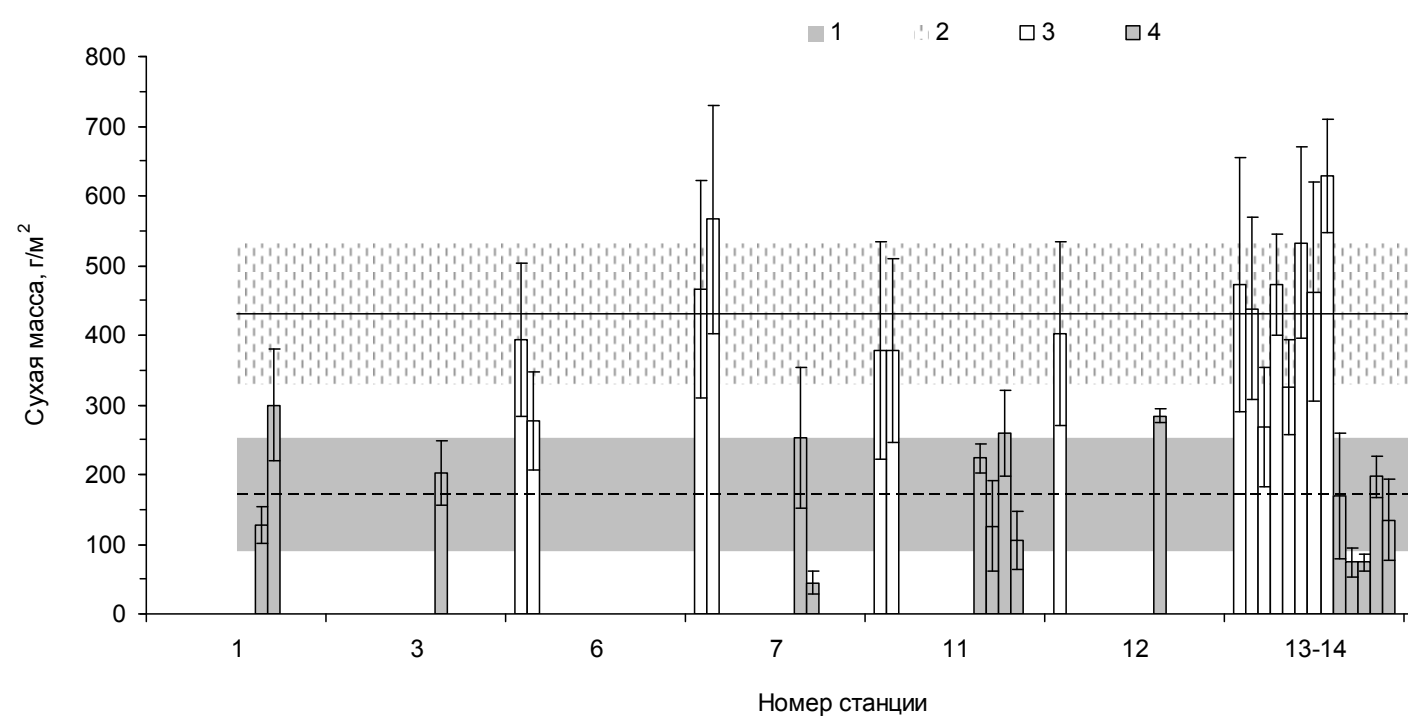

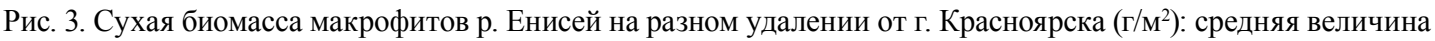
в мелководной зоне рипали $(\mathrm{H}<0,7$ м) - сплошная линия и в глубоководной зоне $(\mathrm{H}>0,8$ м $)$ - прерывистая линия: 1 - стандартное отклонение средней величины биомассы в мелководной зоне; 2 - то же для глубоководной зоны; 3 - средние величины биомассы для отдельных точек отбора в глубоководной зоне ( \pm станд. отклон.); 4 - то же для мелководной зоны. Расположение станций относительно г. Красноярска по течению р. Енисей: № 1 - 14 км выше Красноярска по течению реки; остальные станции расположены ниже Красноярска: № 3 - 26 км, № 6 - 87 км, № 7 - 92 км, № 11 - 272 км, № 13-14 - 324-235 км

массу на станции 13 в 2007 г. был 57 \%, доля рдеста блестящего - 43 \% при общей биомассе растений $(269 \pm 86) \Gamma / \mathrm{M}^{2}(\mathrm{n}=7)$.

Средняя фитомасса в сообществах макрофитов, занимавших наибольшую площадь проективного покрытия, на участках отбора проб в мелководной зоне составила $(172 \pm 81) \Gamma / \mathrm{M}^{2}(\mathrm{n}=15)$, что в 2,5 раза меньше $(p<0,01)$ средней биомассы макрофитов в глубоководной зоне (рис. 3). Наиболее высокие величины фитомассы в мелководной зоне (310 $\left.\pm 125 \Gamma / \mathrm{M}^{2}, \mathrm{n}=4\right)$ зарегистрированы для монодоминантного (99\% от общей биомассы) сообщества рдеста не идентифицированного нами до вида (Potamogeton sp.), который, возможно, является формой или гибридом рдеста блестящего и часто встречается в мелководной зоне Енисея. В относительно небольших по площади монодоминантных сообществах рдеста стеблеобъемлющего (данные не приведены на рис. 3), встреченных в мелковод- ной зоне, фитомасса варьировала в диапазоне 135-300 г/м², при этом доминант составлял 66100 \% фитомассы. В небольших по площади сообществах рдеста гребенчатого, доминировавшего на уровне 70-99 \%, фитомасса варьи-

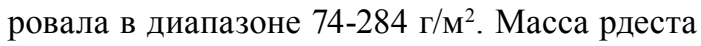
гребенчатого обычно невысока; например, на станции 14 в 2008 г. при доминировании этого вида на уровне 99 \% биомасса растений

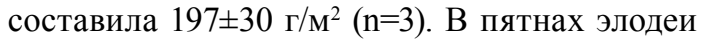
канадской на мелководье биомасса достигала $338 \pm 21(\mathrm{n}=3)$, из них на долю доминанта приходилось $92 \%$.

Из полученных данных можно заключить, что глубина столба воды является ключевым параметром, контролирующим рост растений в зоне рипали Енисея. В мелководной зоне рост погруженных макрофитов ограничен низким уровнем воды. Мы наблюдали увеличение длины растений (например, рдеста стеблеобъемлющего и др.) по 
мере возрастания глубины, соответственно увеличивается и фитомасса. В глубоководной части рипали длина стеблей макрофитов может значительно (в два раза) превышать глубину за счет более высокой скорости течения. Кроме того, у экземпляров, произрастающих на высокопроточных участках, отмечаются большие размеры листьев, чем на участках с замедленным течением. Возможно, это различие обусловлено более интенсивным поступлением биогенных элементов на проточных участках, как предположил в своей работе В.Г. Папченков (2003а). Для водоемов Среднего Поволжья показано, что популяции водных растений в проточных водоемах (речные) на четверть продуктивнее, чем озерные и водохранилищные (Папченков, 2003а, Шарапов и др., 2013). Таким образом, глубину и интенсивность водообмена (скорость течения) можно отнести к числу основных факторов, определяющих интенсивность роста биомассы макрофитной растительности в глубоководной и мелководной прибрежных зонах р. Енисей.

В работе В.Г. Папченкова (2003а) выявлена прямая зависимость биомассы фитоценозов от величин проективного покрытия доминирующих в них видов. Показано, что монодоминантные сообщества макрофитов с высоким проективным покрытием доминирующего вида имеют большую биомассу, чем многовидовые сообщества с низким проективным покрытием доминанта. В полученных нами данных для мелководной зоны рипали р. Енисей подобная тенденция также просматривается, но, чтобы выявить корреляционную зависимость, необходимо провести полноценный статистический анализ с привлечением дополнительных данных.

В период наших наблюдений интенсивность зарастания проток сильно варьировала в зависимости от уровня воды. Так, осе- нью 2006 г. макрофитная растительность на изучаемом нами участке Енисея была развита очень слабо из-за аномально высокого уровня воды, который поддерживался в течение летнего периода сбросами Красноярской ГЭС. Через год после паводка площади зарослей макрофитов, особенно в глубоководной зоне, в местах нашего регулярного отбора еще не восстановились. На некоторых участках наблюдалась смена доминирующего комплекса после паводка 2006 г. Так, вблизи с. Атаманово, в протоке о-ва Атамановский (станция 6), произошло значительное развитие урути колосистой в местах, где ранее доминировал рдест блестящий.

На исследованном нами участке Енисея макрофитная растительность находится под влиянием антропогенного загрязнения химической и радиационной природы. В биомассе макрофитов, отобранных ниже Красноярска, зарегистрированы повышенные концентрации некоторых тяжелых металлов (Анищенко и др., 2010), а на участке, расположенном ниже ГХК (г. Железногорск, рис. 1), в биомассе макрофитов и в донных отложениях регистрируются техногенные радионуклиды (Болсуновский и др., 2007). Наибольшую дозу облучения макрофиты р. Енисей получают вблизи ГХК (район с. Атаманово) (Болсуновский и др., 2007), по мере удаления от ГХК по течению реки дозовая нагрузка на растения снижается. Ранее был выявлен повышенный уровень клеток с хромосомными аномалиями в корнях элодеи канадской (Болсуновский и др., 2007) в зоне радиационного загрязнения Енисея. Однако значительного изменения биомассы и видового разнообразия макрофитов по мере удаления от ГХК на основе полученных нами данных установить не удалось. Вероятно, на уровне биомассы макрофитов токсический эффект, наблюдаемый на цитогенетическом уровне, пока не проявился, 
либо его следует искать с использованием иных методов.

Продуктивность служит интегральным показателем состояния макрофитного сообщества. Как правило, продуктивность макрофитов оценивается как максимальная биомасса, выросшая за вегетационный сезон, умноженная на коэффициент, учитывающий естественные потери (опад). Сроки достижения наибольших величин фитомассы зависят от климатических условий и могут не совпадать у разных видов, однако показано, что большинство макрофитов достигает максимальной массы после периода цветения (Шарапов и др., 2013). Как упоминалось выше, основу глубоководной прибрежной растительности на высокопроточных участках Енисея формирует рдест блестящий. Потери биомассы рдеста блестящего за вегетационный сезон достигали $13,3 \%$, а в среднем составили $(3,1 \pm 3,4) \%(\mathrm{n}=17)$. Потери биомассы рдеста стеблеобъемлющего, часто доминирующего на участках с замедленным течением (в заводях и протоках), были больше, до 36,3 \% у отдельных растений, а в среднем $(11,6 \pm 7,8) \%$ ( $\mathrm{n}=37)$. Следовательно, коэффициенты пересчета биомассы в продукцию рдеста блестящего и рдеста стеблеобъемлющего составили в среднем 1,0 и 1,1. Близкие по величине коэффициенты $(1,1-1,2)$ использовались для оценки продукции тех же видов рдестов в других водоемах (Корелякова, 1972; Распопов, 1973). Таким образом, продукция рдеста блестящего в монодоминантных сообществах этого вида в Енисее равна его максимальной биомассе и составляет 250-650 г/M $\mathbf{M}^{2}$, а продукция рдеста стеблеобъемлющего в глубоководной зоне составила, по нашей оценке, 360 г/M². Beличины опада могут значительно отличаться у разных видов макрофитов, а также у одних и тех же видов в разных водоемах, в том числе за счет варьирования длительности вегетаци- онного сезона (Папченков, 2003б). Продолжительность вегетационного сезона погруженных макрофитов на среднем участке Енисея в значительной степени зависит от водного и температурного режима, задаваемого Красноярской ГЭС, а также сбросов коммунальных вод. Некоторые виды макрофитов могут вегетировать в зимний период на незамерзающем участке Енисея, который простирается в суровые зимы до 80 км, а в теплые до 300 км от Красноярской ГЭС (Карта реки..., 2008). Так, массовые жизнеспособные заросли элодеи канадской, цветущие в январе, сохраняются вблизи с. Есаулово (станция 4) (табл. 1, рис. 1) вплоть до мая. Массовое отмирание рдестов (стеблеобъемлющего и блестящего) начинается в сентябре, но время его наступления различается на участках с разной скоростью течения и на разном удалении от Красноярска. В середине октября вблизи с. Атаманово (станция 5) еще встречались куртины шелковника, урути и рдеста блестящего с относительно небольшим количеством отмерших листьев. Однако значительного роста рдестов после созревания семян, в сентябре и октябре, по-видимому, уже не происходило, чего нельзя сказать о шелковнике и урути. Поэтому сделанную нами оценку опада у рдеста блестящего и рдеста стеблеобъемлющего можно считать близкой к действительной. Вероятно, она может несколько варьировать на разных участках и в разные сезоны. Таким образом, с учетом поправок на опад продукция двух массовых видов рдестов в Енисее незначительно отличается от их максимальной биомассы, чего, вероятно, нельзя сказать о других массовых видах, таких как элодея.

\section{Заключение}

Исследование биомассы и видового состава погруженных макрофитов Енисея на среднем участке реки от г. Красноярска до 
устья р. Ангары (пос. Стрелка) показало, что макрофитная растительность четко разделяется по видовому составу и биомассе на глубоководную (Н>0,8 м) и мелководную (Н<0,7 м). Биомасса глубоководной растительности $\left(431 \pm 101\right.$ г сух. массы/ $\left.{ }^{2}\right)$ в два раза пре-

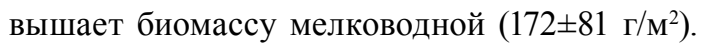
Глубину и интенсивность водообмена можно отнести к числу основных факторов, определяющих интенсивность роста биомассы макрофитной растительности в глубоководной и мелководной прибрежных зонах Енисея. Глубоководная растительность представлена в основном монодоминантными сообществами рдеста блестящего на высокопроточных участках и рдеста стеблеобъемлющего на участках со сниженной скоростью течения. На мелководье значительную площадь проективного покрытия занимают как полидоминантные, так и монодоминантные сообщества видов, характерных для мелководной зоны (элодеи канадской, рдеста гребенчатого, рдеста стеблеобъемлющего и др.). Оценка по индексу Шеннона-Маргалефа показала более высокое видовое разнообразие мелководной макрофитной растительности по сравнению с глубоководной на большинстве участков. Величины опада, оцененные для двух до- минирующих видов рдестов, близки к аналогичным величинам, полученным другими авторами. Полученные величины биомассы и опада доминирующих видов позволяют оценить продукцию глубоководной растительности на среднем участке Енисея. Для оценки продукции мелководной растительности требуются дополнительные исследования. Анализ укосов макрофитной растительности Енисея не выявил значительных изменений видового разнообразия погруженных макрофитов и их биомассы на разном удалении от источников антропогенного загрязнения.

\section{Благодарности}

Автор выражает глубокую благодарность сотрудникам лаборатории радиоэкологии ИБФ СО РАН за помощь в сборе и подготовке проб фитомассы, а также Е.А. Ивановой (СФУ, г. Красноярск), Л.М. Киприяновой (ИВЭП СО РАН, г. Новосибирск) и А.А. Боброву (ИБВВ PAН, пос. Борок) за помощь в идентификации отдельных видов растений. Автор благодарен анонимным рецензентам за ценные замечания и информационные ресурсы, позволившие улучшить работу. Работа частично поддержана грантом программы Президиума РАН «Биологическое разнообразие» № 30,5.

\section{Список литературы}

1. Абакумов В.А. (Ред.) (1983) Руководство по методам гидробиологического анализа поверхностных вод и донных отложений. Ленинград: Гидрометеоиздат, 240 с.

2. Алимов А.Ф., Бульон В.В., Гутельмахер Б.Л., Иванова М.Б. (1979) Применение биологических и экологических показателей для определения степени загрязнения природных вод. Водные ресурсы 5: 137-150.

3. Анищенко О.В., Гладышев М.И., Кравчук Е.С., Калачева Г.С., Грибовская И.В. (2010) Оценка антропогенного загрязнения р. Енисей по содержанию металлов в основных компонентах экосистемы на участках, расположенных выше и ниже г. Красноярска. Журнал Сибирского федерального университета. Биология 3 (1): 82-98.

4. Бобров А.А. (1999) Флора водотоков Верхнего Поволжья. Бот. журн. 84 (1): 93-104.

5. Бобров А.А., Чемерис Е.В. (2003) Описание растительных сообществ в водоемах и водотоках и подходы к их классификации методом Браун-Бланке. В: Папченков В.Г., Бобров А.А., 
Щербаков А.В., Лисицына Л.И. (ред.) Гидроботаника: методология, методы: Материалы Школы по гидроботанике (п.Борок, 8-12 апреля 2003 г.). Рыбинск: ОАО «Рыбинский Дом печати», с. 105-117.

6. Бобров А.А., Чемерис Е.В. (2005) Очерк растительного покрова малых рек Колокша и Вожа (Ярославская область). Бюл. МОИП. Отд. биол. 110 (5): 52-64.

7. Бобров А.А., Чемерис Е.В. (2011) Речная растительность бассейна Ветлуги (Костромская область). Бюл. МОИП. Отд. биол. 116 (2): 44-62.

8. Болсуновский А.Я., Муратова Е.Н., Суковатый А.Г., Пименов А.В., Санжараева Е.А., Зотина Т.А., Седельникова Т.С., Паньков Е.В., Корнилова М.Г. (2007) Радиоэкологический мониторинг реки Енисей и цитогенетические характеристики водного растения Elodea canadensis. Радиац. биология. Радиоэкология. 47 (1): 63-73.

9. Губанов И.А., Киселева К.В., Новиков В.С., Тихомиров В.Н. (2002) Иллюстрированный определитель растений Средней России. Т. 1. Папоротники, хвощи, плауны, голосеменные, покрытосеменные (однодольные). М.: Т-во научных изданий КМК, 526 с.

10. Дрюккер В.В., Петрова В.И. (1988) Бактериопланктон реки Енисей. Новосибирск: Наука, 96 с.

11. Евженко К.С. (2010) Флора и растительность водных объектов долины реки Тара (Омская область). Вестник Томского государственного университета 333: 157-160.

12. Зотина Т.А. (2013) Находка бразильской элодееи Egeria densa Planch. (Hydrocharitaceae) в реке Енисей. Turczaninowia 16 (3): 60-63.

13. Зотина Т.А., Трофимова Е.А., Медведева М.Ю., Болсуновский А.Я. (2013) Биотестирование донных отложений р. Енисей с использованием водного растения Elodea canadensis. Известия Самарского научного центра РАН 15: 579-584.

14. Киприянова Л.М. (2009) Растительность реки Берди и ее притоков (Новосибирская область, Западная Сибирь). Растительность России 12: 21-38.

15. Киприянова Л.М. (2013) Водная и прибрежно-водная растительность рек Чулым и Каргат (Западная Сибирь). Растительность России 22: 63-77.

16. Корелякова И.Л. (1972) Продукция высшей растительности Киевского водохранилища. В: Цееб Я.Я., Майстеренко Ю.Г. (ред.) Киевское водохранилище (гидрохимия, биология, продуктивность). Киев: Наукова думка, с. 155-162.

17. Красноборов И.М., Ломоносова М.Н., Шауло Д.Н., Вибе Е.И., Жирова О.С., Королюк Е.А., Красников А.А., Снытко О.Н., Тупицына Н.Н. (2000) Определитель растений Новосибирской области. Новосибирск: Наука, Сибирское предприятие РАН, 492 с.

18. Кропачева М.Ю., Чугуевский А.В., Мельгунов М.С., Богуш А.А. (2011) Поведение ${ }^{137} \mathrm{Cs}$ в системе почва-ризосфера-растение на примере поймы реки Енисей. Сибирский экологический журнал 5: 719-727.

19. Куриленко В.В., Осмоловская Н.Г. (2007) Биоиндикаторная роль высших растений при диагностике загрязнений водных экосистем на примере малых водоемов г. Санкт-Петербурга. Водные ресурсы 34 (6): 757-764.

20. Мордухай-Болтовской Ф.Д. (ред.) (1975) Методика изучения биогеоценозов внутренних водоемов. М.: Наука, 240 с.

21. Папченков В.Г. (2003а) Надземная биомасса макрофитов водоёмов и водотоков Среднего Поволжья. Биол. внутр. вод 1: 40-48. 
22. Папченков В.Г. (2003б) Продукция макрофитов вод и методы ее изучения. В: Папченков В.Г., Бобров А.А., Щербаков А.В., Лисицына Л.И. (ред.) Гидроботаника: методология, методы: Материалы Школы по гидроботанике (п. Борок, 8-12 апреля 2003 г.). Рыбинск: ОАО «Рыбинский Дом печати», с. 137-144.

23. Приймаченко А.Д., Шевелева Н.Г., Покатилова Т.Н., Пырина И.Л., Белавская А.П., Баженова О.П. (1993) Продукционно-гидробиологические исследования Енисея. Новосибирск: Наука, 197 с.

24. Распопов И.М. (1973) Фитомасса и продукция макрофитов Онежского озера. В: И.И.Николаев (отв.ред.) Микробиология и первичная продукция Онежского озера. Л.: Наука, с. 123-143.

25. Токарь О.Е. (2005) Фитомасса и продуктивность макрофитов р. Ишим на тюменском участке. Вестник экологии, лесоведения и ландшафтоведения 5: 125-130.

26. Карта реки Енисей от Красноярской ГЭС до устья реки Ангара. (2008) СПб: ФГУ «Енисейречтранс», ГБУ «Волго-Балт», 91 с.

27. Черепанов С.К. (1995) Сосудистые растения России и сопредельных государств (в пределах бывшего СССР). СПб.: Мир и семья, 992 с.

28. Шарапов А.В., Чемерис Е.В., Бобров А.А. (2013) Запасы надземной фитомассы речных макрофитов Верхнего Поволжья и её сезонная динамика. Раст. ресурсы 49 (1): 48-56.

29. Щербина С.С. (2009) Флора сосудистых растений Центральносибирского государственного биосферного заповедника и сопредельных территорий. Turczaninowia 12 (1): 71-241.

30. Ceschin S., Zuccarello V., Caneva G. (2010) Role of macrophyte communities as bioindicators of water quality: Application on the Tiber River basin (Italy). Plant Biosyst. 144 (3): 528-536.

31. Chepinoga V.V., Bergmeier E., Rosbakh S.A., Fleckenstein K.M. (2013) Classification of aquatic vegetation (Potametea) in Baikal Siberia, Russia, and its diversity in a northern Eurasian context. Phytocoenologia 43 (1-2): 127-167.

32. Fabris M., Schneider S., Melzer A. (2009) Macrophyte-based bioindication in rivers - A comparative evaluation of the reference index (RI) and the trophic index of macrophytes (TIM). Limnologica 39 (1): 40-55.

33. Zotina T.A. (2008) The biomass of macrophytes at several sites of the upper reaches of the Yenisei River. Journal of Siberian Federal University. Biology 1 (1): 102-108. 